\title{
Differential impact of various reactive oxygen species (ROS) on HIF-1a/p53 direct interaction in SK-N-MC neuroblastoma cells
}

\author{
Elham Parandavar and Razieh Yazdanparast ${ }^{*}$ (1)
}

\begin{abstract}
Background: A vital property of eukaryotic cells physiology is their rather quick response to variation of oxygen tension, mainly by a transcription factor known as hypoxia-inducible factor-1 (HIF-1). Aside from its transcriptional regulation, other mechanisms, such as post translational modifications and protein-protein interactions, the interaction between HIF-1 $a$ and p53 has attracted more attention mainly due to simultaneous enhancement in the protein levels of these two anti- and pro-apoptotic vital transcriptional factors within the ROS-stressed cells.

Methods: In this study, we measured cell viability following exposure of the cells to $\mathrm{H}_{2} \mathrm{O}_{2}$, menadione and Cobalt Chloride by MTT, and ROS content was measured under the same condition. The immunoblotting technique has been used to establish the presence and amount of Caspase, HIF-1a and p53 proteins. Then, the effect of different ROS on interaction between HIF-1a and p53 proteins was examined by co-immunoprecipitation.
\end{abstract}

Results: The results showed that cells viability and intracellular ROS content were modulated in response to menadione, $\mathrm{H}_{2} \mathrm{O}_{2}$ and Cobalt Chloride. These agents had different influence on HIF-1a signaling pathways as well as its interactions with $\mathrm{p} 53$ protein. It appeared that direct communication between HIF-1a and p53 proteins by ROS stresses, under both normoxic and hypoxic conditions, was governed by HIF-1a at a certain induced level.

Conclusions: Our data indicated that stabilization, a prerequisite for communication, of HIF-1a is dependent to the types of free radicals.

Keywords: HIF-1a, p53, Hypoxia, Interaction, Apoptosis

\section{Background}

All sorts of life rely on molecular oxygen within a narrow range of its tension. Variation in the intracellular level of oxygen has been associated with various physiological consequences naming oxidative stress resulting from surplus level of $\mathrm{O}_{2}$ (hyperoxia), ischemia and cellular demise arising from moderate-to-severe level of $\mathrm{O}_{2}$ depletion (hypoxia-anoxia) [1-3]. In general, physiological responses to hypoxia are categorized either as acute (quick-onset with short duration) or chronic (delayedonset with prolonged duration). Acute responses are believed to be associated with variation in the activity

*Correspondence: ryazdan@ut.ac.ir Institute of Biochemistry and Biophysics, University of Tehran, P.O. Box 13145-1384 Tehran, Iran of the existing proteins while, chronic responses are believed to entail variation in the expression level of the affected target genes $[2,4]$.

One of the well-studied factors induced in response to hypoxia is hypoxia inducible factor 1 (HIF-1), a heterodimeric protein composed of two subunits of HIF- $1 \alpha$ and HIF-1 $\beta$ (also known as aryl hydrocarbon nuclear receptor transporter, ANRT). Both subunits belong to basic HelixLoop-Helix per/Arnt/Sim (bHLH-PAS) transcription factor family $[5,6]$. Apparently, HIF- $\beta$ is constitutively expressed independent of the level of molecular oxygen and thus, it is a stable protein regardless of the physiological stresses. However, if not the expression level, but the stability of the HIF- $1 \alpha$ subunit is regulated by the $\mathrm{O}_{2}$ level $[7,8]$. In other words, HIF- $1 \alpha$ acts as the $\mathrm{O}_{2}$-sensor and the regulatory sub unit of HIF-1 complex. 
Despite the well accepted survival function of HIF- $1 \alpha$ under mild hypoxia, recently it has been shown that HIF- $1 \alpha$ trans-activate some of the pro-apoptotic genes such as NIP , NIX, RT801 and P27 implying that HIF-1 $\alpha$ is also involved in cell demise under oxygen-stressed environment $[4,8,9]$. These dual behaviors have in part been contributed to HIF-1 $\alpha$ direct and/or indirect interaction with other proteins including p53 with as yet debatable physiological significance.

Under normoxia, the intracellular p53 and HIF- $1 \alpha$ contents are low. Under this resting condition, p53 is subjected to Mdm2 ubiquitination and proteasomal degradation. However, under tight stress situation such as DNA damage or hypoxia, the ATM/ATR-dependent phosphorylation of p53 leads to its polymerization, p300 binding followed by its transcriptional activation $[9,10]$. On the other hand, $\mathrm{O}_{2}$-dependent regulation of HIF- $1 \alpha$ is believed to be mediated through its $\mathrm{O}_{2}$-dependent degradation domain (ODD) containing two regulatory proline residues. Under normoxia, hydroxylation of Asn 803 residue of HIF- $1 \alpha$ by HIF- $1 \alpha$ hydroxylase prevents p300 binding to HIF-1 $\alpha$. Besides, hydroxylation of prolines 402 and 546 within the ODD domain by proline hydroxylases (PHDs) initiates the binding of von Hippel-Lindou (pVHL) protein resulting in HIF-1 $\alpha$ ubiquitination followed by proteasomal degradation. Under hypoxia, HIF$1 \alpha$-hydroxylase and PHDs are inactive leading to HIF- $1 \alpha$ accumulation, nuclear translocation followed by HIF- $1 \beta$ and p300 bindings [4] with the final outcome of HIF- $1 \alpha$ stabilization and transcriptional activation. In other words, under moderate to severe hypoxia both p53 and HIF- $1 \alpha$ are stabilized via competition for p300 co-activator which normally exists at minute amounts. Which one of these transcriptional factor succeed the competition would depend on the extent of oxygen-dependent stabilization of each of these two cellular adaptation factors. It is generally accepted that p53 stabilization occurs at severe hypoxic environment $\left(\left[\mathrm{O}_{2}\right]<1 \%\right)$ while, HIF- $1 \alpha$ accumulation happens at much higher $\mathrm{O}_{2}$ level $\left(\left[\mathrm{O}_{2}\right]>3 \%\right)$.

The aforementioned mutual effect among p53 and HIF- $1 \alpha$ might be due in part to the direct physical interaction between the two HIF- $1 \alpha$ natively unfolded motifs within its acidic ODD domain with the basic DNA binding core of p53 $[11,12]$ and/or to the indirect interaction between HIF- $1 \alpha$ and p53 via Mdm2 [13]. Anyhow, these interactions could bring about either transcriptional inactivation of $\mathrm{p} 53$, due to the masking of p53 DNA binding core by HIF- $1 \alpha$, leading to lower level of apoptosis or it could cause p53 transcription activation mainly due to the higher level of p53 binding to the co-activator, p300, and thus, higher level of apoptosis. Of note, some studies have shown that hypoxia-induced p53, albeit binding to target gene promotors, is incapable of trans-activating them [14]. In support of the former view, recently it has been shown that under hypoxia, Jab1 (Jun activation domain binding protein 1 ) competes with $\mathrm{p} 53$ for binding to HIF- $1 \alpha$ leading to its stabilization and enhanced survival [15].

Despite the continuing debate on the physiological consequences of HIF- $1 \alpha / \mathrm{p} 53$ interactions and regarding the role of oxygen tension in ROS production and the proven role of ROS in HIF- $1 \alpha$ stabilization [16], in this investigation we wished to evaluate modulation, if any, of HIF- $1 \alpha$ and $\mathrm{p} 53$ direct interaction by the types of oxygen free radicals (ROS) mainly hydroxy free radicals ( $\dot{\mathrm{O}} \mathrm{H})$ and superoxide anion radicals $\left(\dot{\mathrm{O}}_{2}^{-}\right)$whose intracellular contents are augmented under hypoxia [16].

\section{Results and discussion}

Cell viability modulation by the oxidants

It is well established that menadione and $\mathrm{H}_{2} \mathrm{O}_{2}$ induce oxidative stress in the exposed cells via superoxide anion and hydroxy free radicals, respectively [17]. Exposure of SK-N-MC cells to various doses of menadione $(0-30 \mu \mathrm{M})$ and $\mathrm{H}_{2} \mathrm{O}_{2}(0-200 \mu \mathrm{M})$ affected the viability of the cells dose-dependently relative to un-exposed control cells as evident from Fig. 1a, b. Based on this figure, the $\mathrm{IC}_{50}$ doses were found to be around 10.96 and $107.61 \mu \mathrm{M}$ for menadione and $\mathrm{H}_{2} \mathrm{O}_{2}$, respectively.

\section{Estimation of the intracellular ROS levels generated by the oxidants}

The intracellular ROS content of each treated SK-N-MC cell sample was assessed by $2^{\prime}, 7^{\prime}$-dichloro fluorescein diacetate (DCFH-DA). Proportional to the intracellular ROS content, DCFH is oxidized to $2^{\prime}, 7^{\prime}$-dichloro fluorescein (DCF) which is a fluorophore and a means of quantification of the ROS content. As shown in Fig. 2, the SK-N-MC intracellular ROS content enhanced by 2.46and 1.30 -fold among the cells exposed for $24 \mathrm{~h}$ to the $\mathrm{IC}_{50}$ concentration of menadione $(12 \mu \mathrm{M})$ and $\mathrm{H}_{2} \mathrm{O}_{2}(100 \mu \mathrm{M})$, respectively. Interestingly, $\mathrm{CoCl}_{2}$, as a hypoxia-inducing agent and as an oxidant also enhanced the ROS content of the cells at its $\mathrm{IC}_{50}(100 \mu \mathrm{M})$ by almost 1.6-fold (Fig. 2) and in accordance to the present literature [18-20].

\section{Apoptosis induction in SK-N-MC cells by the oxidants}

As shown in Fig. 3a, b, following $24 \mathrm{~h}$ of exposure of the cells to $\mathrm{H}_{2} \mathrm{O}_{2}(100 \mu \mathrm{M})$ and/or Menadione $(12 \mu \mathrm{M})$, the number of apoptotic cells increased from $3.60 \%$ in the untreated control cells to 46.30 and $40.88 \%$ in a caspase3-dependant manner (Fig. 3c), respectively. Despite the higher level of ROS generation in $\mathrm{CoCl}_{2}$-treated cells $(100 \mu \mathrm{M})$ relative to $\mathrm{H}_{2} \mathrm{O}_{2}$-treated ones (Fig. 2), the extent of cell apoptosis was lower, by almost a 

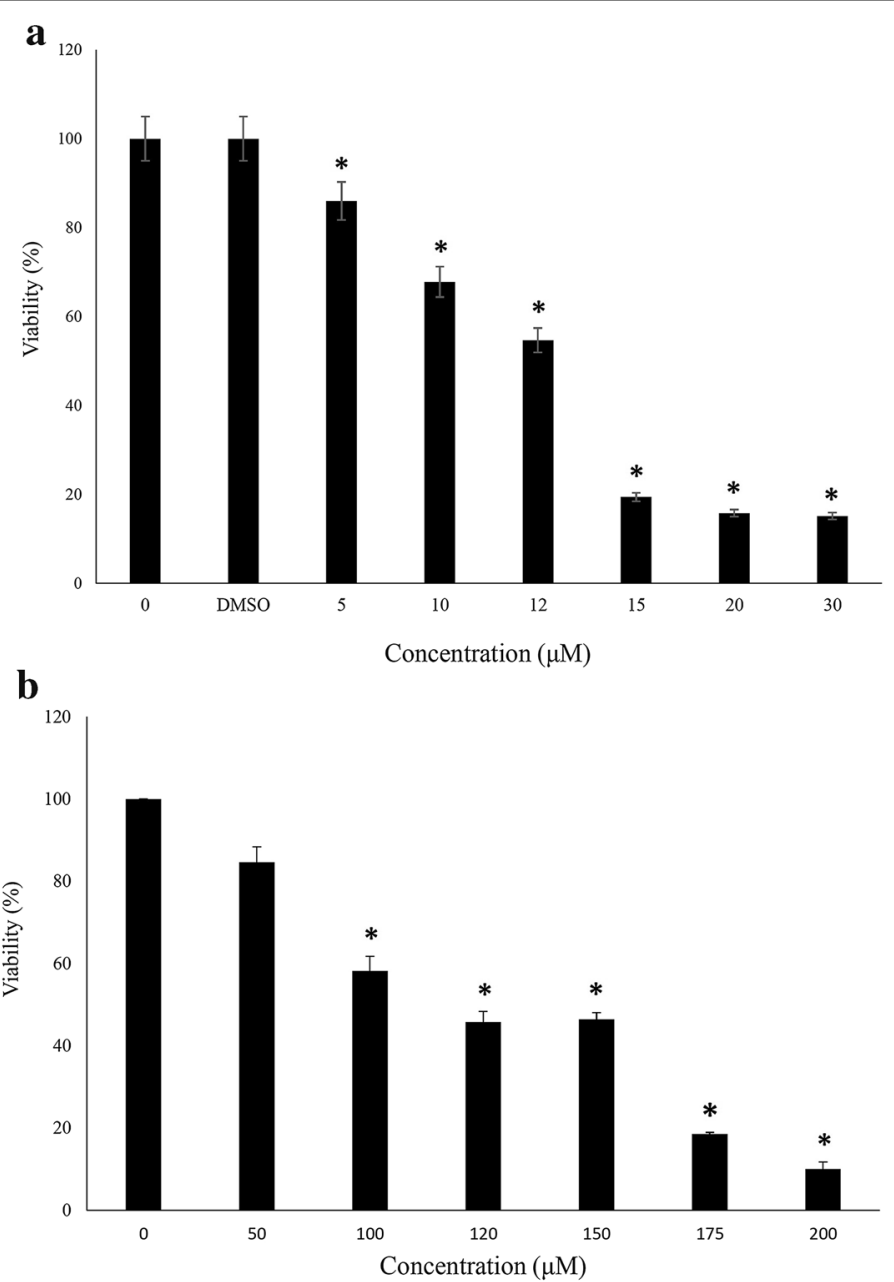

Fig. 1 Effects of menadione and $\mathrm{H}_{2} \mathrm{O}_{2}$ on SK-N-MC cell viability. The cells $\left(2.5 \times 10^{4}\right) 12 \mathrm{~h}$ after seeding have been exposed to various concentrations of Menadione $\mathbf{a}$ or $\mathrm{H}_{2} \mathrm{O}_{2}$ b for $24 \mathrm{~h}$, followed by measuring the cells viabilities relative to untreated control cells. The data represent the mean \pm SD of at least 3 independent measurements. Asterisk significantly different from control cells $(p<0.05)$

factor of six, relative to the extent of apoptosis among the $\mathrm{H}_{2} \mathrm{O}_{2}$-treated cells. This response might in part be due to the types of reactive free radicals generated within the cells in response to stimuli. Physiologically, ROS (mainly $\dot{\mathrm{O}}_{2}^{-}$, $\dot{\mathrm{OH}}$ and OONO) are primarily produced as superoxide anions within the inner membrane space of mitochondria, its matrix and to a lesser extent on the outer mitochondrial membrane. While the majority of $\dot{\mathrm{O}}_{2}^{-}$ within the matrix is converted to $\mathrm{H}_{2} \dot{\mathrm{O}}_{2}$ by the mitochondrial superoxide dismutase, part of $\dot{\mathrm{O}}_{2}^{-}$produced in the inner membrane space leaks to the cell cytosol where it is converted to $\mathrm{H}_{2} \mathrm{O}_{2}$ by the cytosolic SOD. In addition, it has been shown that high $\dot{\mathrm{O}}_{2}^{-}$level will act as an oxidant of [4Fe-S] cluster-containing proteins leading to $\mathrm{OH}$ production from $\mathrm{H}_{2} \mathrm{O}_{2}$ by making $\mathrm{Fe}^{2+}$ ion available for the Fenton reaction [21]. Hydroxyl free radicals, in turn, could react with nitric oxide (NO) to form peroxynitrite radicals (OONO), both being highly reactive and toxic to the biological systems [22]. Cellular peroxisomes are other site of $\mathrm{H}_{2} \mathrm{O}_{2}$ (but not $\dot{\mathrm{O}}_{2}^{-}$) generation. However, most of $\mathrm{H}_{2} \mathrm{O}_{2}$ is converted to $\mathrm{H}_{2} \mathrm{O}$ and $\mathrm{O}_{2}$ by the peroxisome catalase. Thus, ROS production within the cells could be either mitochondria-dependent, as it is the case in hypoxia, or it can be mitochondria-independent as in the case of $\mathrm{CoCl}_{2}$ induced ROS production. This situation might bring about differential cellular responses as it will be shown in the coming sections.

\section{HIF-1a stabilization in response to the types of oxygen free radicals}

Hypoxic-inducible factor (HIF-1) is known as a master regulator of a vast array of genes in response to 


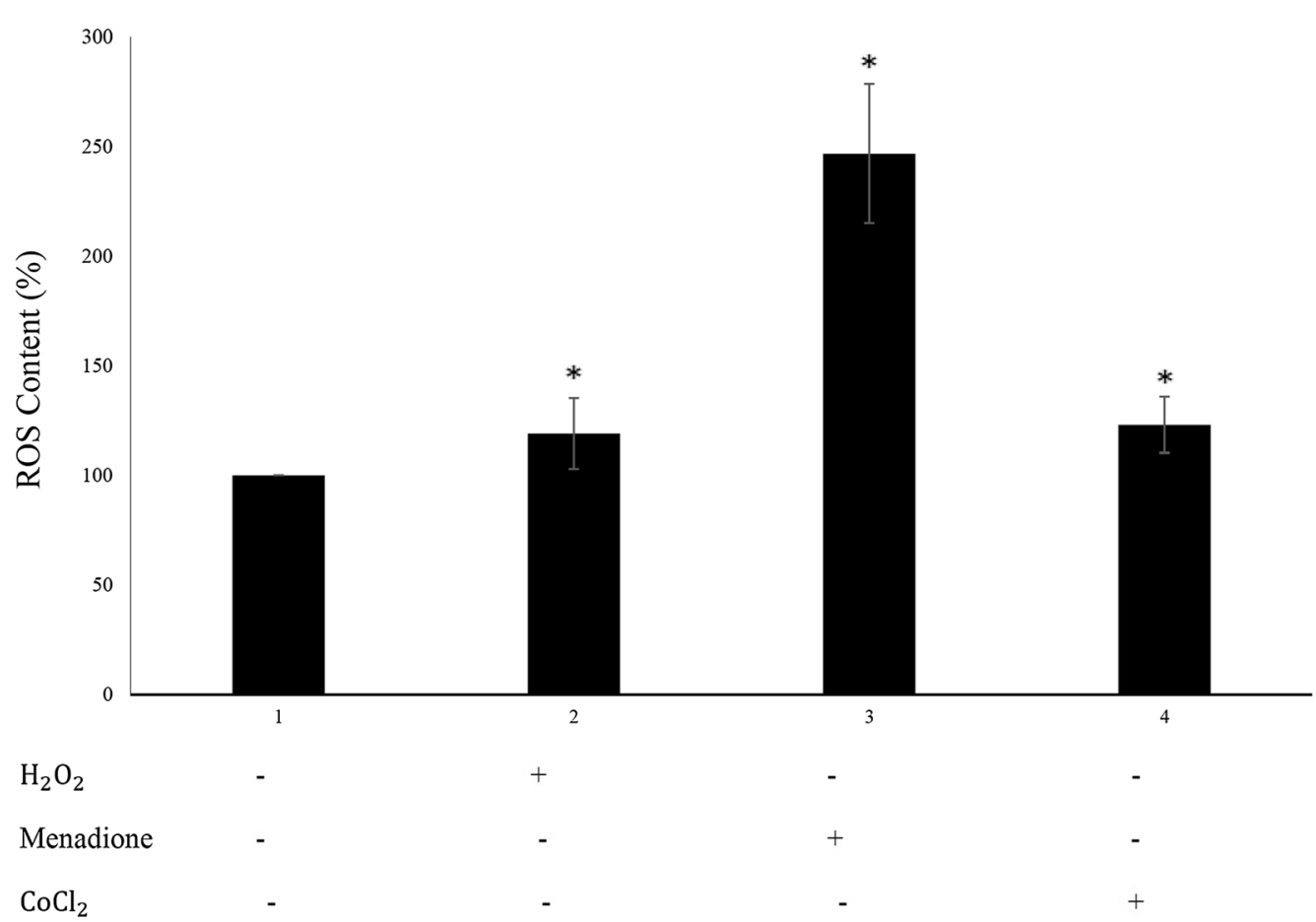

Fig. 2 The interacellular ROS content of the oxidant-treated SK-N-MC cells. The cells were treated with either $\mathrm{H}_{2} \mathrm{O}_{2}(100 \mu M)$, menadione (12 $\mu M$ ) or $\mathrm{CoCl}_{2}(100 \mu \mathrm{M})$ for $24 \mathrm{~h}$ and then the ROS content was measured using DCFH-DA probe. The result are the mean \pm SD of three experiments. Asterisk significantly different from the untreated control cells $(p<0.05)$

intracellular oxygen concentration. The regulatory subunit of HIF-1 complex is HIF-1 $\alpha$ which is degraded under normoxic oxygen concentration of $21 \%$ but it is stabilized at hypoxic $(3 \%)$ and anoxic $(<0.1 \%)$ oxygen level as a means of cellular adaption to stress [23, 24]. It has also been shown that other oxygen-independent mechanisms such as mitochondrial-dependent ROS production at low $\left[\mathrm{O}_{2}\right]$ could lead to HIF-1 $\alpha$ stabilization $[16,25,26]$. This latter mode of HIF-1 $\alpha$ stabilization could be prevented by antioxidants such as NAC and ascorbate while hypoxic stabilization of HIF- $1 \alpha$ is not affected by the same compounds, clearly implying that at low level of $\mathrm{O}_{2}$ tension, HIF-1 $\alpha$ stabilization occurs via ROS while hypoxic stabilization is regulated by molecular oxygen. Regarding the proven role of ROS on HIF- $1 \alpha$ accumulation, we compared the extent of HIF- $1 \alpha$ stabilization by various types of oxygen free radicals under the influence of menadione $\left(\dot{\mathrm{O}}_{2}^{-}\right.$generator), $\mathrm{H}_{2} \mathrm{O}_{2}$ (ÖH generator) and $\mathrm{CoCl}_{2}$ (a hypoxic mimetic and $\mathrm{OH}$ and ONOO generator) at the $\mathrm{IC}_{50}$ concentration level of each compound.

Based on western blot analyses as shown in Fig. 4 (top), the three types of free radicals were capable of stabilizing HIF- $1 \alpha$ though to different extent after $24 \mathrm{~h}$ of exposure. As evident from Fig. 4 (bottom), $\mathrm{CoCl}_{2}$ at $100 \mu \mathrm{M}$, which is believed to induce hypoxic environment [27,
28], caused the highest HIF- $1 \alpha$ accumulation relative to menadione at $12 \mu \mathrm{M}$ and/or $\mathrm{H}_{2} \mathrm{O}_{2}$ at $100 \mu \mathrm{M}$ which have been applied at normoxic condition. From this observation, it could be concluded that higher HIF- $1 \alpha$ stabilization occurs at lower oxygen tension.

\section{p53 stabilization in response to the type of oxygen free radicals}

In contrast to firm acceptance of hypoxia-induced HIF- $1 \alpha$ stabilization, the accumulation (stabilization) of p53 transcriptional factor under hypoxic-to-anoxic environment is a subject of dispute in the present day literature [16, 25-28]. Under normoxia, the half-life of wild-type p53 is short mainly due to $\mathrm{Mdm} 2$ guided cytosolic proteasomal degradation. However, under severe oxygen depletion $(<0.2 \%), \mathrm{Mdm} 2$ binding to the $\mathrm{N}$-terminus region of $\mathrm{p} 53$ is apparently blocked due to the p53-phosphorylation of that domain, leading to p53 nuclear accumulation [2931]. It has been shown, however, that hypoxia-induced p53 is transcriptionally incompetent in trans-activating many of the previously characterized target genes such as Bax, Bak, p21 [31], implying that under hypoxic environment the traditional role of p53 is lost. However, it has been shown that the traditional function could be restored under hypoxic environment by addition of a 
$\mathbf{a}$
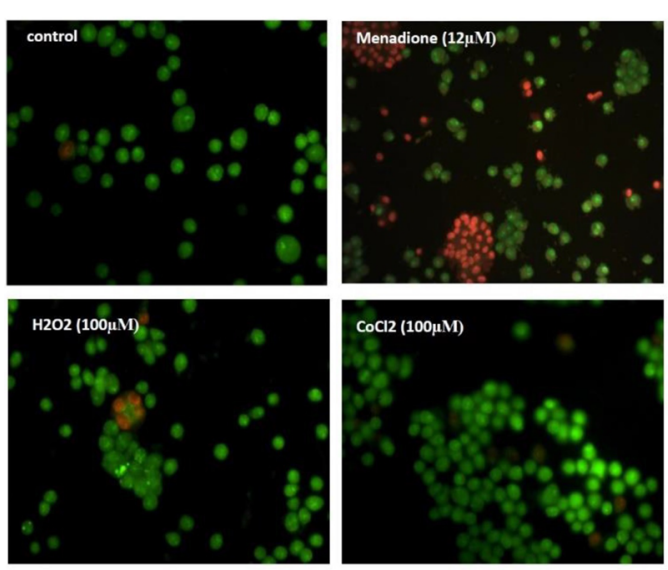

b

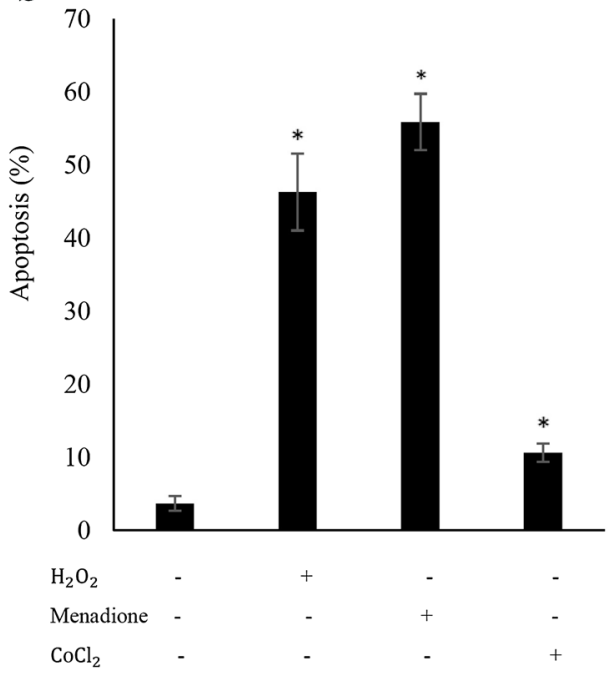

c

Cleaved Caspase $3(21 \mathrm{kDa})$

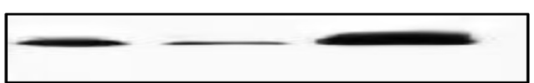

Tubulin $(50 \mathrm{kDa})$
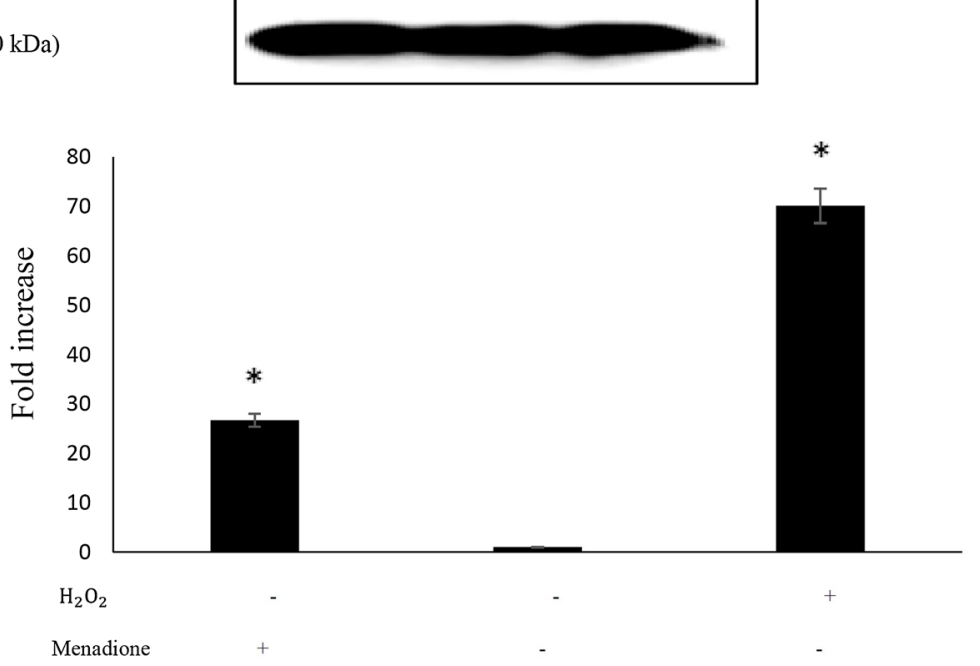

Fig. 3 Evaluating apoptosis in SK-N-MC cells. a Cells were treated with $100 \mu \mathrm{M} \mathrm{H}_{2} \mathrm{O}_{2}, 12 \mu \mathrm{M}$ menadione and $100 \mu \mathrm{M} \mathrm{CoCl}$, for $24 \mathrm{~h}$ and then cells were visualized with Ethidium bromide/acridine orange dual-staining method. $\mathbf{b}$ The extent of apoptosis was determined based on counting apoptic cells in ten randomly chosen region by fluorescence microscope. c Caspase3 generation, as an apoptotic marker under oxidative stress condition, was analyzed using western blot technique. Asterisk significantly different from untreated control cells $(p<0.05)$

DNA damaging agent [32]. Regarding the supporting views on the presence of oxidative stress under chronic exposure to hypoxia and its subsequent influence on the cellular signaling elements, we planned to evaluate the response of p53 transcriptional factor to different types of ROS. As shown in Fig. 5, all three ROS generators, at the concentration level to induce $50 \%$ cellular apoptosis, have almost the same effect on p53 stabilization. This response is clearly different from HIF-1 $\alpha$ response to ROS exposures (Fig. 4).

Despite the high level of p53 accumulation, the extent of $\mathrm{CoCl}_{2}$-induced apoptosis among the treated cells is much lower than that of the menadione and/or $\mathrm{H}_{2} \mathrm{O}_{2}$-treated cells (Fig. 3a, b). This could partly be attributed to the transcriptional incompetency of p53 under hypoxia (generated by $\mathrm{CoCl}_{2}$ ) as explained above. 


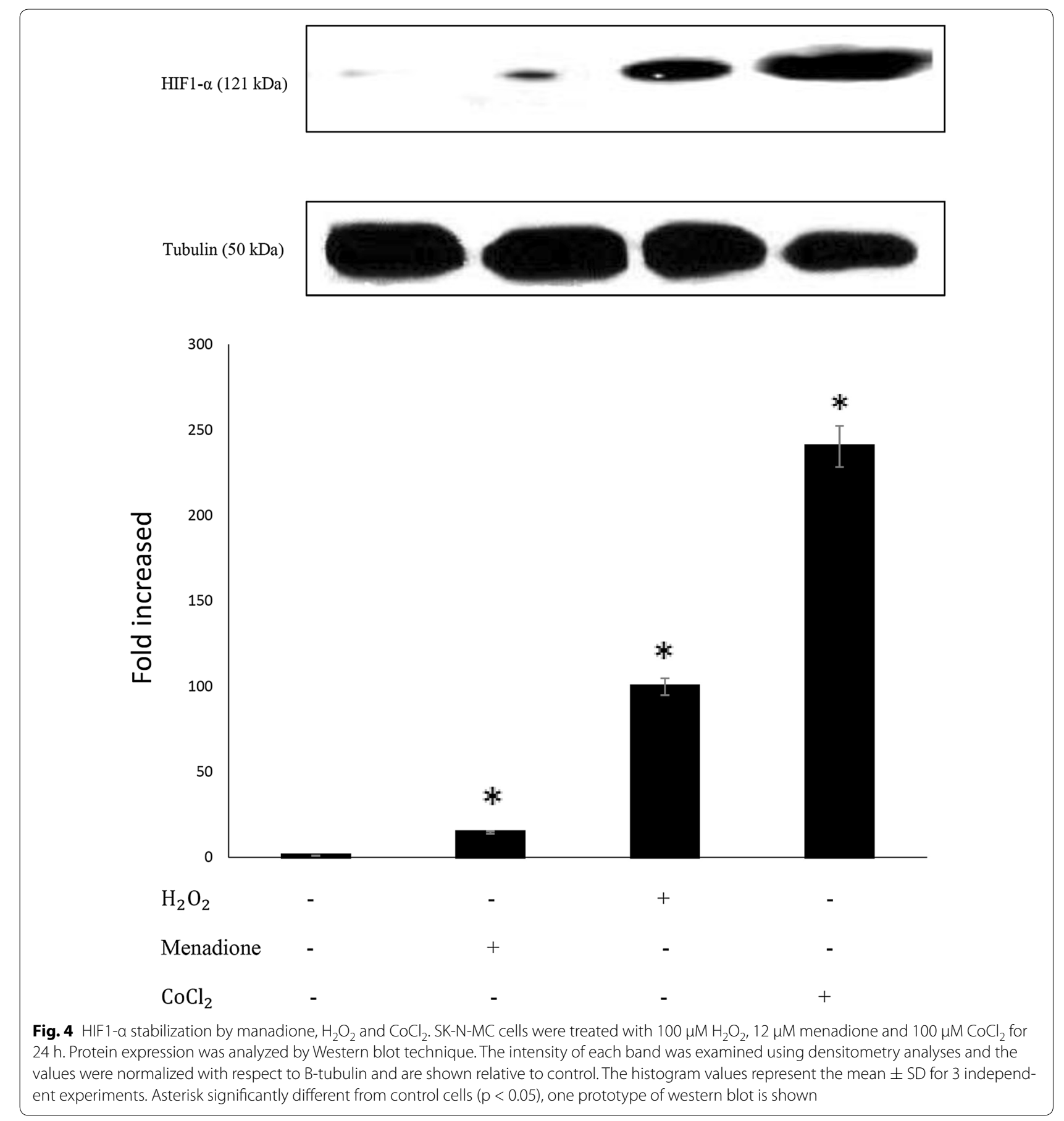

\section{HIF-1a/p53 interaction in response to types of ROS}

While there is universal agreement on cross-talk between HIF- $1 \alpha$ and p53 under various stresses specifically hypoxia, the physiological significance of this interaction remains highly disputable. The primary requirement for direct and/or indirect interaction relies on the extent of expression and stabilization of each of these transcriptional factors which in turn is dependent on the intracellular oxygen tension. Evidently, at initial phase of hypoxia with an oxygen tension of around $3 \%$, HIF-1 $\alpha$ undergoes phosphorylation followed by its binding to HIF-1 $\beta$ (ARNT) and p300 with subsequent transcriptional activation. Apparently at this level of oxygen concentration, the expression of p53 is suppressed [33]. As the hypoxic condition persist for longer time and the oxygen tension drops to lower than $1 \%$, the 


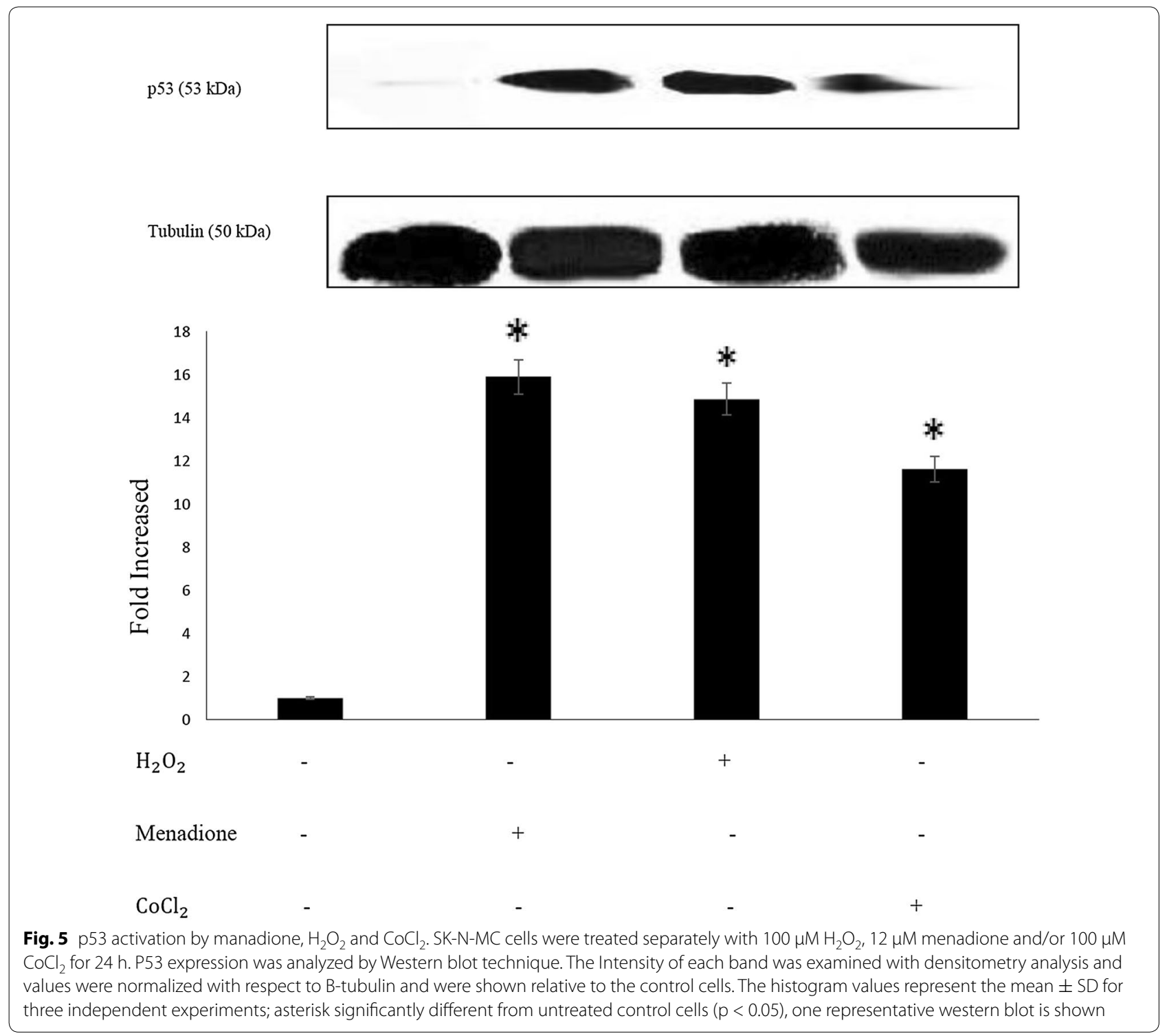

expression level of p53 and dephosphorylation of HIF- $1 \alpha$ starts to increase leading to HIF- $1 \alpha$ binding to p53 and its transcriptional inactivation [33]. Using biophysical approaches, Sanehez et al. [11] have shown that HIF-1 $\alpha$ directly binds to $\mathrm{p} 53$ core domain through two distinct binding sites located at residues 530-698 (referred to as $\mathrm{N}$-terminus trans activating domain, N-TAD) and residues 402-603 (termed ODD region), meaning that one HIF- $1 \alpha$ molecule interacts with a p53 dimer.

Having in mind the influence of hypoxia-induced ROS on the stabilization of both p53 and HIF- $1 \alpha$, we evaluated the impact of the types of ROS, under both normoxic and imitated hypoxic environments, on HIF- $1 \alpha / \mathrm{p} 53$ interaction following $24 \mathrm{~h}$ exposure of SK-N-MC cells to the $\mathrm{IC}_{50}$ dose of menadione $(12 \mu \mathrm{M}), \mathrm{H}_{2} \mathrm{O}_{2}(100 \mu \mathrm{M})$ and/or
$\mathrm{CoCl}_{2}(100 \mu \mathrm{M})$. The cell free system of each cell sample was subjected to immunoprecipitation using anti-p53 antibody followed by western blot analyses using antip53 and/or anti- HIF-1 $\alpha$ antibodies to evaluate the possibility of HIF- $1 \alpha$ and p53 interaction. As depicted in Fig. 6, under normoxic and $\mathrm{H}_{2} \mathrm{O}_{2}$ environments, the complex of HIF- $1 \alpha / p 53$ has been formed. Despite the fact that the extent of p53 accumulation and also the extent of apoptosis among the cells treated with either $\mathrm{H}_{2} \mathrm{O}_{2}$ or menadione were almost comparable (Figs. 5 and 3, respectively), but no stable interaction between HIF- $1 \alpha$ and p53 was registered in menadione treated cells (Fig. 6 column 3). Similarly, under hypoxic environment induced by $\mathrm{CoCl}_{2}$ (at $100 \mu \mathrm{M}$ ), the complex of HIF-1 $\alpha / \mathrm{p} 53$ did not form (Fig. 6, column 4), though p53 stabilization occurred to 


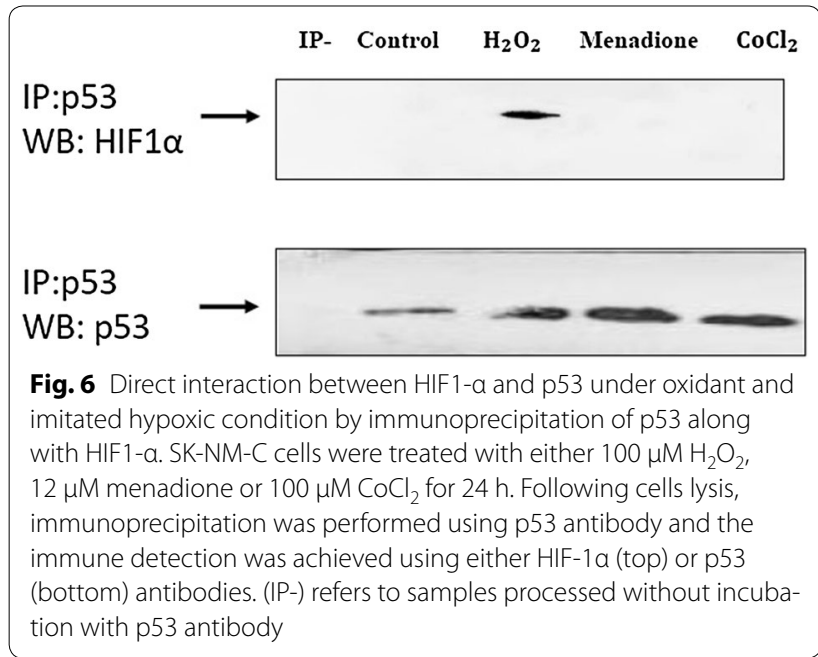

the same extent as under $\mathrm{H}_{2} \mathrm{O}_{2}$ and/or menadione treatment (Fig. 5).

Based on results presented in Figs. 2, 4 and 5, the difference in the pattern of HIF- $1 \alpha$ and p 53 communication under normoxic and non-mitochondrial dependent hypoxic environment could be attributed to two factors:

First, the difference might arise due to the types of free radicals primarily generated in the cells from $\mathrm{H}_{2} \mathrm{O}_{2}$, menadione and/or $\mathrm{CoCl}_{2}$. Secondly, and based on results presented in Fig. 4, it can be concluded that ROS dependent expression level of HIF- $1 \alpha$ apparently plays the key role in HIF- $1 \alpha / \mathrm{p} 53$ communication meaning that the expression level beyond a certain limit (which requires to be determined) interrupts the interaction between HIF- $1 \alpha$ and p53. Based on our results, expression level of HIF- $1 \alpha$ beyond 2.5 -fold has probably prevented the association between HIF- $1 \alpha$ and p53 proteins (Figs. 4 and 6). Certainly, additional work is required to firmly approve this claim and to establish the exact range of HIF- $1 \alpha$ level needed to initiate and/or to interrupt the communication.

Furthermore, based on results presented in Figs. 3 and 6 , we cannot clearly draw a link between the extent of cellular apoptosis and the presence or absence of communication between HIF- $1 \alpha$ and p53: Menadione and $\mathrm{H}_{2} \mathrm{O}_{2}$ induced almost the same extent of apoptosis among the cells while only $\mathrm{H}_{2} \mathrm{O}_{2}$ caused the dimerization of HIF- $1 \alpha$ with p53 but menadione did not. On the other hand, Menadione and $\mathrm{CoCl}_{2}$ did not induce dimerization of HIF-1 $\alpha$ with p53 while both induce cellular apoptosis to various extent.

In order to come up with a clearly defined physiological role for HIF- $1 \alpha$ and p53 complex, it is essential to determine not only the transcriptional activity of each component of the complex under our experimental condition but also to identify the relevant target genes expressed by each transcriptional factor while in contact with the other component. These investigations are in progress in our lab and will be published in due course.

\section{Conclusions}

In our study, we showed, parallel to the present literature, that intracellular ROS augmentation occurred under normoxic and/or imitated hypoxic environments leading to various degree of apoptosis among the cells. Secondly, our data clearly supported the stabilization of two of the vital transcriptional factors in charge of cellular adaption to various stresses. Thirdly, our results, in line with the literature, approved direct communication between HIF- $1 \alpha$ and p53 under the stress environment. Fourthly, our data clearly supported the impact of types of oxygen free radicals (ROS) on modulation of direct interaction between HIF- $1 \alpha$ and p53 proteins. We believe the capability to modulate the HIF- $1 \alpha$ and p53 direct interaction, simply by small oxidant/antioxidant molecules, would provide a novel approach to defend against various oxidative stress damages pending the disclosure of the biological and physiological significances of HIF- $1 \alpha$ and p53 communication.

\section{Experimental \\ Materials}

Hydrogen peroxide $\left(\mathrm{H}_{2} \mathrm{O}_{2}\right)$ and dimethyl sulfoxide (DMSO) obtained from Merck (Darmstadt, Germany). Ethidium bromide, acridine orange, and Triton X-100 were purchased from Pharmacia LKB Biotechnology (Sweden). Ethylene diamine tetraacetic acid (EDTA), Tergitol, Anti-B-tubulin and protein G on Sepharose fast flow were from Sigma Aldrich (Germany). MTT [3-(4,5-dimethylthiazol-2,3-diphenyltetrazolium bromide], phenyl methyl sulphonyl fluoride (PMSF), 2,7-dichloroflurescein diacetate (DCFH-DA) were obtained from Molecular Probe (Eugene, Oregon, USA), Anti-HIF1 $\alpha$, Anti-p53 were from Santa Cruz Biotechnology, Inc. (Texas, USA). ECL kit was purchased from Amersham-Pharmacia (Piscataway, NJ, USA). Mouse/ Rabbit horse radish peroxidase-conjugated secondary antibodies were from Bio Source (Nivelles, Belgium). The cell culture medium (RPMI-1640), penicillin-streptomycin, and fetal bovine serum (FBS) were purchased from Gibco BRL (Life technology, Paisely, Scotland). The culture plates were from Nunc (Denmark). Human SK$\mathrm{N}-\mathrm{MC}$ neuroblastoma cells were obtained from Pasteur institute (Tehran, Iran).

\section{Cell culture}

The SK-N-MC cells were cultured in RPMI-1640 medium supplemented with $10 \%(\mathrm{v} / \mathrm{v})$ fetal bovine serum (FBS) 
and $1 \%$ streptomycin-penicillin. Cells were maintained at $37{ }^{\circ} \mathrm{C}$ in the incubator with $5 \% \mathrm{CO}_{2}$-humidified atmosphere.

\section{Treatments}

Cells were treated with $\mathrm{H}_{2} \mathrm{O}_{2}$, menadione and/or Cobalt Chloride at different doses. $\mathrm{H}_{2} \mathrm{O}_{2}$ was diluted with deionized water and then its concentration was determined by its absorption at $240 \mathrm{~nm}$. Menadione was dissolved in dimethyl sulfoxide (DMSO) and then diluted with the culture medium to the desired concentration. The concentration of DMSO in the culture medium kept lower than $0.1 \%$. Cobalt Chloride was dissolved in deionized water to the desired concentration.

\section{Hypoxia induction}

Imitation of hypoxic condition was achieved by the exposure of the cells to Cobalt Chloride solution. Cells were seeded at a density of $7.5 \times 10^{5}$ cells $/ \mathrm{ml}$ and incubated for $24 \mathrm{~h}$ at $37{ }^{\circ} \mathrm{C}$. Then, they were treated with $100 \mu \mathrm{M}$ Cobalt Chloride for different time intervals. The cells' viability was determined by MTT assay to establish the $\mathrm{IC}_{50}$. The remaining experiments were done at a $\mathrm{CoCl}_{2}$ Concentration below its $\mathrm{IC}_{50}$.

\section{Cell viability measurement}

Cell viability was assessed using the MTT assay which determines the extent of mitochondrial dehydrogenase activity in living cells. SK-N-MC cells were seeded into 96-well plates at a density of $2.5 \times 10^{4}$ cells/well in $200 \mu \mathrm{l}$ of medium. After $12 \mathrm{~h}$, cells were treated with different concentration of $\mathrm{H}_{2} \mathrm{O}_{2}$, menadione and/or $\mathrm{CoCl}_{2}$ and incubated for $24 \mathrm{~h}$. Then, $10 \mu \mathrm{l}$ of MTT reagent was added to each well, with a final concentration of about $4 \mathrm{mg} / \mathrm{ml}$, followed by the cells incubation for $4 \mathrm{~h}$. Then, the medium was discarded and $100 \mu \mathrm{l}$ DMSO was added to each well. The formazan dye crystals were solubilized at room temperature and the absorbance at $570 \mathrm{~nm}$ was measured with an ELISA reader. Results were presented as the percentage of MTT reduction, assuming that the absorbance of the control cells was $100 \%$.

\section{Determination of reactive oxygen species}

The reactive oxygen content of the cells was measured by DCF-DA probe [34]. Cells were seeded at the stated density. Then, cells were treated with the desired concentrations of each of the drug (menadione, Cobalt Chloride and/or $\mathrm{H}_{2} \mathrm{O}_{2}$ (. After $24 \mathrm{~h}$, cells were collected and washed twice with PBS. Then, equal cell number of each sample was incubated with DCFH-DA probe in a final concentration of $10 \mu \mathrm{M}$ for $30 \mathrm{~min}$. Finally, the fluorescent intensity was monitored at $485 \mathrm{~nm}$.
Fluorescence microscopy evaluation of the apoptotic cells Dual ethidium bromide/acridine orange (EtBr/Ao) cell staining was used to study apoptosis. In this approach, the normal cells get stained green while the apoptotic cells are stained orange. Treated cells were collected and washed twice with PBS, then, the staining mixture containing acridine orange $(1 \mu \mathrm{g} / \mathrm{ml})$ and ethidium bromide $(1 \mu \mathrm{g} / \mathrm{ml})$ at $1: 1$ ratio was added to the cells. The stained cells were evaluated by an Axoscope 2 plus fluorescence microscope from Zeiss (Gena, Germany).

\section{Immunoblot evaluations}

The control and each of the oxidant-treated cell samples were collected and lysed using the lysis buffer $(100 \mathrm{mM}$ Tris- $\mathrm{HCl}, \mathrm{pH}=7.5,1 \%$ Triton $\mathrm{X}-100,1 \%$ sodium dodecyl sulphate (SDS), $100 \mathrm{mM} \mathrm{NaCl}, 2 \mathrm{mM}$ ethylenediamine tetraacetate, $3 \mathrm{mM}$ sodium orthovanadate, $1 \mathrm{mM} \mathrm{NaF}$, $1 \mathrm{mM}$ phenyl methyl sulfonyl fluoride, $1 \mu \mathrm{g} / \mathrm{ml}$ pepstatine and $1 \mathrm{mM} \mathrm{DTT}, 10 \mu \mathrm{g} / \mathrm{ml}$ leupeptine. Total protein concentration was measured by the Lowry's method and $100 \mu \mathrm{g}$ protein content of each sample was loaded on a 10 or $12 \%$ SDS-PAGE. Afterward, the resolved proteins were electro blotted to a pieces of PVDF membrane for $2 \mathrm{~h}$. The membrane was then blocked by $5 \%(\mathrm{w} / \mathrm{v})$ nonfat dry milk/TBST (Tris-base $20 \mathrm{mM}, \mathrm{NaCl} 137 \mathrm{mM}$ and Tween-20.5\%) for $90 \mathrm{~min}$ at room temperature. The blocked membrane was incubated with the diluted primary antibody following the manufacture's instruction for an overnight at $4{ }^{\circ} \mathrm{C}$ and after three time washing, each membrane was incubated with the anti-rabbit or antimouse horse radish peroxidase (HRP)-conjugated secondary antibody at a predetermined concentration for $90 \mathrm{~min}$ at room temperature. The proteins were detected by an ECL kit according to the manufacturer's instruction.

\section{Immunoprecipitation}

For immunoprecipitation, the cells were seeded at the appropriate density and treated by the desired concentrations of menadione, Cobalt Chloride and/or $\mathrm{H}_{2} \mathrm{O}_{2}$ for $24 \mathrm{~h}$. Then, the cells were washed twice with PBS, lysed with RIPA buffer containing $50 \mathrm{mM}$ Tris- $\mathrm{HCl}$ (pH 8), $150 \mathrm{mM}$ $\mathrm{NaCl}, 1 \% \mathrm{NP}-40,0.5 \%$ sodium deoxy cholate, $0.1 \%$ SDS. Afterwards, equal protein content $(200 \mu \mathrm{g})$ of each sample was incubated with recommended amount of anti-HIF1- $\alpha$ protein under low agitation overnight at $4{ }^{\circ} \mathrm{C}$, subsequently the slurry was mixed with appropriate amount of protein G-agarose fast flow beads and incubated at $4{ }^{\circ} \mathrm{C}$ for $12 \mathrm{~h}$. After this step, supernatant was discarded and the beads were washed 3 times with the washing buffer $(50 \mathrm{mM}$ Tris$\mathrm{HCl}, \mathrm{pH} 8,150 \mathrm{mM} \mathrm{NaCl}, 1 \% \mathrm{NP}-40)$. Loading buffer was added and samples were boiled for $5 \mathrm{~min}$. Finally, an aliquot of each sample was loaded on a SDS-PAGE gel and the band detection was achieved by ECL detection technique. 


\section{Statistical analysis}

Data were expressed as percent of values of untreated control cells, and each value represents the mean \pm SD $(\mathrm{n}=3)$. For IC50, MTT data were analyzed by compusyn software. For western blots, data were normalized with respect to tubulin by image $\mathrm{j}$ software and the significant differences between the means of the treated and untreated cells were calculated by unpaired student's $t$ test and $\mathrm{P}<0.05$ was considered significant.

\section{Authors' contributions}

Both authors have made substantial contributions to the followings: the conception and design of the study, analysis, interpretation of data, drafting the article and final approval of the version to be submitted. Both authors read and approved the final manuscript.

\section{Competing interests}

The authors declare that they have no competing interests.

\section{Consent for publication}

Both authors agree for publication.

\section{Ethics approval and consent to participation}

Not relevant.

\section{Funding}

Both authors thank the Research Council of University of Tehran for the financial support of this investigation.

\section{Publisher's Note}

Springer Nature remains neutral with regard to jurisdictional claims in published maps and institutional affiliations.

Received: 23 July 2017 Accepted: 30 September 2017

Published online: 10 October 2017

\section{References}

1. Semenza GL. HIF-1, $\mathrm{O}_{2}$, and the 3 PHDs: how animal cells signal hypoxia to the nucleus. Cell. 2001;107(1):1-3.

2. Semenza GL. Hypoxia, clonal selection, and the role of HIF-1 in tumor progression. Crit Rev Biochem Mol Biol. 2000;35(2):71-103.

3. Brown JM. The hypoxic cell a target for selective cancer therapyeighteenth Bruce F. Cain memorial award lecture. Cancer Res. 1999;59(23):5863-70.

4. Kumar S, Vaidya M. Hypoxia inhibits mesenchymal stem cell proliferation through HIF1a-dependent regulation of P27. Mol Cell Biochem. 2016:415(1-2):29-38.

5. Wang GL, Semenza GL. Purification and characterization of hypoxiainducible factor 1. J Biol Chem. 1995;270(3):1230-7.

6. Wang GL, Jiang B-H, Rue EA, Semenza GL. Hypoxia-inducible factor 1 is a basic-helix-loop-helix-PAS heterodimer regulated by cellular $\mathrm{O}_{2}$ tension. Proc Natl Acad Sci. 1995;92(12):5510-4.

7. Bárdos Jl, Ashcroft M. Negative and positive regulation of HIF-1: a complex network. Biochimica et Biophysica Acta Rev Cancer. 2005;1755(2):107-20.

8. Huang LE, Gu J, Schau M, Bunn HF. Regulation of hypoxia-inducible factor 1a is mediated by an O2-dependent degradation domain via the ubiquitin-proteasome pathway. Proc Natl Acad Sci. 1998:95(14):7987-92.

9. Sowter HM, Ratcliffe PJ, Watson P, Greenberg AH, Harris AL. HIF-1-dependent regulation of hypoxic induction of the cell death factors BNIP3 and NIX in human tumors. Cancer Res. 2001;61 (18):6669-73.

10. Schmid T, Zhou J, Brüne B. HIF-1 and p53: communication of transcription factors under hypoxia. J Cell Mol Med. 2004;8(4):423-31.
11. Sánchez-Puig N, Veprintsev DB, Fersht AR. Binding of natively unfolded HIF-1a ODD domain to p53. Mol Cell. 2005;17(1):11-21.

12. Fels DR, Koumenis C. HIF-1a and p53: the ODD couple? Trends Biochem Sci. 2005;30(8):426-9.

13. Chen D, Li M, Luo J, Gu W. Direct interactions between HIF-1 1 and Mdm2 modulate p53 function. J Biol Chem. 2003;278(16):13595-8.

14. Hammond EM, Giaccia AJ. The role of p53 in hypoxia-induced apoptosis. Biochem Biophys Res Commun. 2005;331(3):718-25.

15. Bae M-K, Ahn M-Y, Jeong J-W, Bae M-H, Lee YM, Bae S-K, et al. Jab1 interacts directly with HIF-1 $\mathrm{a}$ and regulates its stability. J Biol Chem. 2002;277(1):9-12.

16. Chandel N, Maltepe E, Goldwasser E, Mathieu C, Simon M, Schumacker P. Mitochondrial reactive oxygen species trigger hypoxia-induced transcription. Proc Natl Acad Sci. 1998;95(20):11715-20.

17. Czaja MJ, Liu H, Wang Y. Oxidant-induced hepatocyte injury from menadione is regulated by ERK and AP-1 signaling. Hepatology. 2003;37(6):1405-13.

18. Chandel NS, MCClintock DS, Feliciano CE, Wood TM, Melendez JA, Rodriguez AM, et al. Reactive oxygen species generated at mitochondrial complex iii stabilize hypoxia-inducible factor-1 a during hypoxia a mechanism of $\mathrm{O}_{2}$ sensing. J Biol Chem. 2000;275(33):25130-8.

19. Zou W, Yan M, Xu W, Huo H, Sun L, Zheng Z, et al. Cobalt chloride induces PC12 cells apoptosis through reactive oxygen species and accompanied by AP-1 activation. J Neurosci Res. 2001;64(6):646-53.

20. Xi L, Taher M, Yin C, Salloum F, Kukreja RC. Cobalt chloride induces delayed cardiac preconditioning in mice through selective activation of HIF-1a and AP-1 and iNOS signaling. Am J Physiol-Heart Circ Physiol. 2004;287(6):H2369-75.

21. Kotake-Nara E, Saida K. Endothelin-2/vasoactive intestinal contractor: regulation of expression via reactive oxygen species induced by CoCl22, and biological activities including neurite outgrowth in PC12 cells. Sci World J. 2006;6:176-86.

22. Beckman JS, Chen J, Ischiropoulos H, Crow JP. [23] oxidative chemistry of peroxynitrite. Methods Enzymol. 1994;233:229-40.

23. Höckel M, Vaupel P. Tumor hypoxia: definitions and current clinical, biologic, and molecular aspects. J Natl Cancer Inst. 2001;93(4):266-76.

24. Iyer NV, Kotch LE, Agani F, Leung SW, Laughner E, Wenger RH, et al. Cellular and developmental control of $\mathrm{O}_{2}$ homeostasis by hypoxia-inducible factor 1a. Genes Dev. 1998;12(2):149-62.

25. Mansfield KD, Guzy RD, Pan Y, Young RM, Cash TP, Schumacker PT, et al. Mitochondrial dysfunction resulting from loss of cytochrome $\mathrm{c}$ impairs cellular oxygen sensing and hypoxic HIF-a activation. Cell Metab. 2005;1(6):393-9.

26. Valko M, Leibfritz D, Moncol J, Cronin MT, Mazur M, Telser J. Free radicals and antioxidants in normal physiological functions and human disease. Int J Biochem Cell Biol. 2007;39(1):44-84.

27. Sanjuán-Pla A, Cervera AM, Apostolova N, Garcia-Bou R, Víctor VM, Murphy MP, et al. A targeted antioxidant reveals the importance of mitochondrial reactive oxygen species in the hypoxic signaling of HIF-1a. FEBS Lett. 2005;579(12):2669-74.

28. Pan Y, Oprysko PR, Asham AM, Koch CJ, Simon MC. p53 cannot be induced by hypoxia alone but responds to the hypoxic microenvironment. Oncogene. 2004;23(29):4975-83.

29. Hammond EM, Denko NC, Dorie MJ, Abraham RT, Giaccia AJ. Hypoxia links ATR and p53 through replication arrest. Mol Cell Biol. 2002;22(6):1834-43.

30. An WG, Kanekal M, Simon MC, Maltepe E, Blagosklonny MV, Neckers LM. Stabilization of wild-type p53 by hypoxia-inducible factor $1 \mathrm{a}$. Nature. 1998;392(6674):405-8.

31. Wenger RH, Camenisch G, Desbaillets I, Chilov D, Gassmann M. Upregulation of hypoxia-inducible factor-1a is not sufficient for hypoxic/ anoxic p53 induction. Cancer Res. 1998;58(24):5678-80.

32. Koumenis C, Alarcon R, Hammond E, Sutphin P, Hoffman W, Murphy M, et al. Regulation of $\mathrm{p} 53$ by hypoxia: dissociation of transcriptional repression and apoptosis from p53-dependent transactivation. Mol Cell Biol. 2001;21(4):1297-310.

33. Bruick RK. Expression of the gene encoding the proapoptotic Nip3 protein is induced by hypoxia. Proc Natl Acad Sci. 2000;97(16):9082-7.

34. LeBel CP, Ischiropoulos H, Bondy SC. Evaluation of the probe 2', $7^{\prime}$-dichlorofluorescin as an indicator of reactive oxygen species formation and oxidative stress. Chem Res Toxicol. 1992;5(2):227-31. 